\section{Growth of Bioluminescent Xanthomonas campestris pv. vesicatoria in Tomato Cultivars}

\author{
Fenny Dane and Marten H. Dane \\ Department of Horticulture, Auburn University, Auburn, AL 36849
}

Additional index words. Lycopersicon esculentum, genetically engineered microbe

\begin{abstract}
A pathogenic strain of Xanthomonas campestris pv. vesicatoria, causal agent of bacterial spot of tomato (Lycopersicon esculentum Mill.), was genetically engineered to bioluminesce. In planta growth of the bioluminescent strain was similar to that of its parental strain. Movement and growth of the bioluminescent strain in susceptible tomato seedlings after wound inoculation was followed over time with a liquid- $\mathrm{N}$-cooled, chargecoupled device camera. Highly significant differences in bioluminescent bacterial growth were observed in the four tomato cultivars used. Systemic bacterial movement was most pronounced in 'Sunny', which showed population development not only at the inoculation sites but also on several sites in the leaves and at the leaf margins. Bacterial bioluminescence levels in 'Campbell 28' remained significantly lower than those observed in 'Walter' and 'Sunny'. The technique offers unique possibilities for studying host-pathogen interactions and bacterial pathogenesis.
\end{abstract}

Bacterial spot disease of tomato, caused by Xanthomonas campestris pv. vesicatoria $(\mathrm{Xcv})$, is a serious problem in regions with high temperatures and humidity. Xcv enters the host through stomates and wounds, colonizing the intercellular leaf spaces, and affecting all aboveground plant parts (Gitaitis et al., 1992). Partial resistance to Xcv was reported in the tomato cultivar Campbell 28 (Crill et al., 1972), whereas Jones and Scott (1986) reported a source of hypersensitive-type resistance in 'Hawaii 7998'.

Bioluminescence in phytopathogenic bacteria has been used successfully to monitor nondestructively the movement and spread of living bacteria in planta as well as in the field environment (Shaw et al., 1992). A bioluminescent variant of Xcv tomato strain XV171 (obtained from J.B. Jones, Bradenton, Fla.) was constructed using the transposon, $T n 4431$. The transposon, which carries the lux genes of a marine bacterium (Vibrio fischeri) and tetracycline resistance genes was transferred to XV171 through electroporation (Shaw and Kahn, 1993). Initial experiments were conducted with 4-week-old 'Walter' tomato seedlings to compare in planta growth of the bioluminescent bacterial strain (FD922) with that of the parental strain. Results confirmed earlier studies with bioluminescent Xanthomonas campestris pv. campestris in cabbage (Dane and Shaw, 1993; Shaw et al., 1992): in planta growth of the bioluminescent strain was similar to that of its parental strain, and the level of bacterial bioluminescence observed in the host is a function of the bacterial population level.

Received for publication 27 Oct. 1993. Accepted for publication 5 Feb. 1994. Journal no. 11-933570 of the Alabama Agricultural Experiment Station. The cost of publishing this paper was defrayed in part by the payment of page charges. Under postal regulations, this paper therefore must be hereby marked advertisement solely to indicate this fact. used to image bioluminescence in the seedlings by focusing the camera on the seedlings and making a 5-min exposure with the camera cooled to $-110 \mathrm{C}$ (Dane and Shaw, 1993). Firmware was used to extract positional and quantitative data from the images. The method is nondestructive, and individual seedlings were analyzed repeatedly (at 3, 7, 10, 14, 20, and 34 days following inoculation). The data (quanta per plant) were analyzed by the general linear models procedure of SAS (Cary, N.C.).

\section{Results and Discussion}

Highly significant differences in bioluminescent bacterial growth, expressed as quanta per plant, were observed among the tomato cultivars tested (Fig. 1). Three days after inoculation, high bioluminescence levels were present around the inoculation sites in $\approx 75 \%$ of the inoculated leaves. Systemic bacterial movement was most pronounced in 'Sunny' plants, which showed bioluminescent populations on several sites in the leaf and at the leaf margins (Fig. 2). While bioluminescence levels remained low in the 'Campbell 28' leaves and decreased after day 7 in the 'Red Cherry' leaves, high bioluminescence levels were observed over longer periods in 'Sunny' and 'Walter' (Fig. 1). Eventually, bioluminescence levels decreased in all plants. Lesion development was limited and lagged behind bacterial population development. Bioluminescence levels in 'Campbell 28' were significantly lower than those observed in 'Walter' and 'Sunny'. This finding contrasts with results of other studies (Scott and Jones, 1986) and requires more investigation. The technique of fers unique possibilities for studying host-

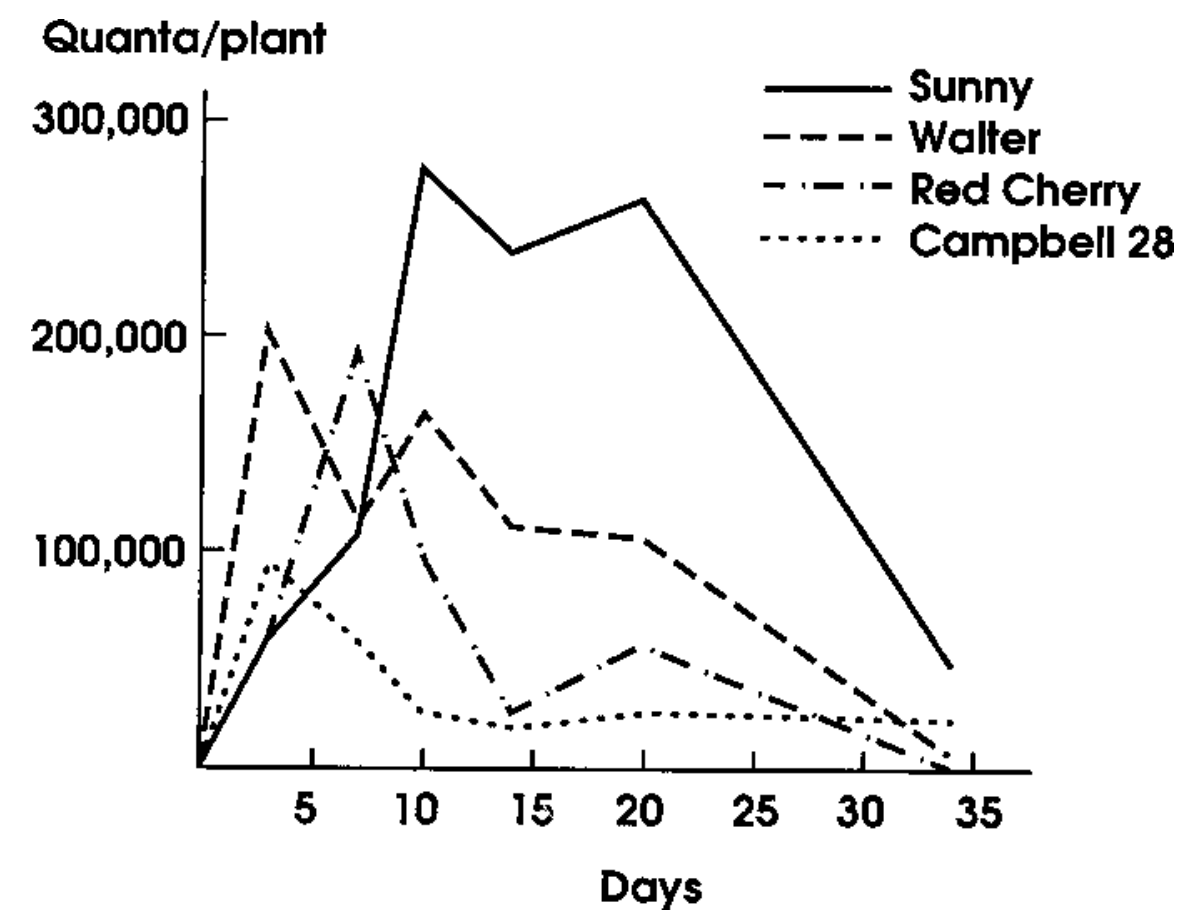

Fig. 1. Bacterial bioluminescence, expressed as the number of pixels or quanta per plant, followed over time from the day of wound inoculation with bioluminescent Xanthomonas campestris pv. vesicatoria. 


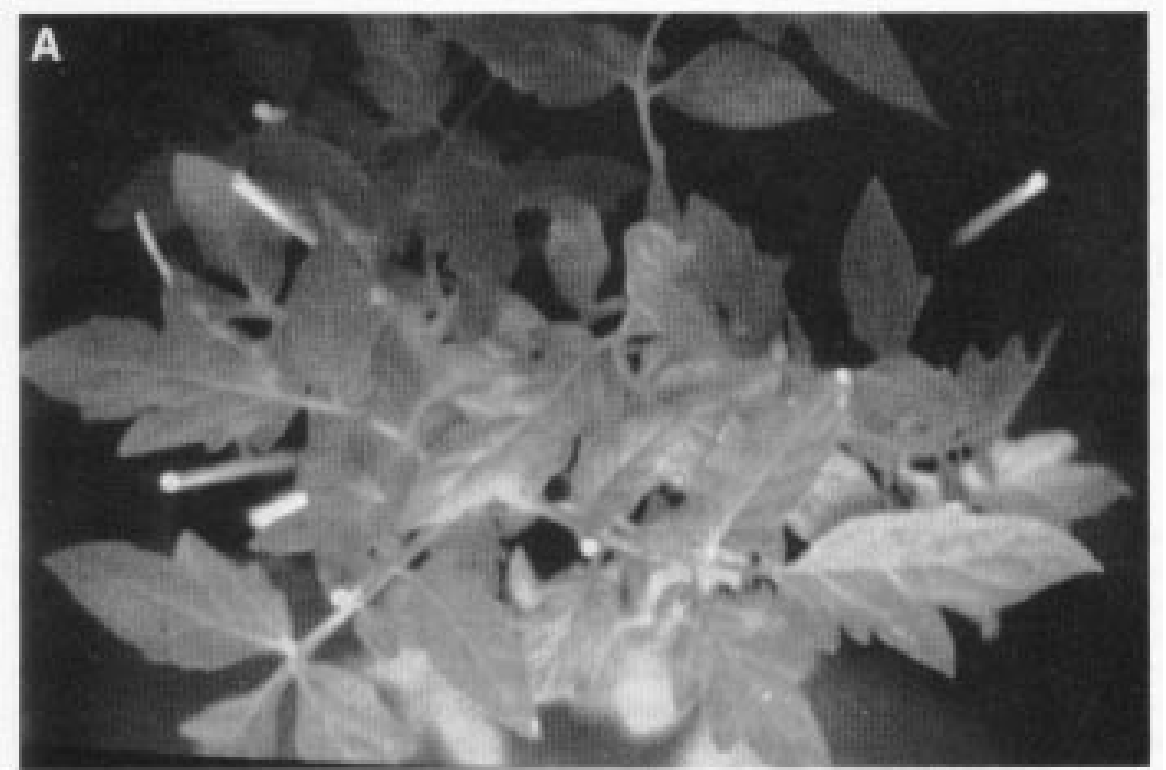

pathogen interactions under various environmental conditions, since it provides a nondestructive means to analyze bacterial growth in planta, and can especially be useful in field epidemiology investigations.

\section{Literature Cited}

Crill, P., J.P. Jones, and D.S. Burgis. 1972. Relative susceptibility of some tomato genotypes to bacterial spot. Plant Dis. Rpt. 56:504-507.

Dane, F. and J.J. Shaw. 1993. Growth of bioluminescent Xanthomonas campestris pv.campestris in susceptible and resistant host plants. Mol. Plant-Microbe Interaction 6:786-789.

Gitaitis, R., S. McCarter, and J.B. Jones. 1992. Disease control in tomato transplants produced in Georgia and Florida. Plant Dis. 76:651-656.

Jones, J.B. and J.W. Scott. 1986. Hypersensitive response in tomato to Xanthomonas campestris pv. vesicatoria. Plant Dis. 70:337-339.

Shaw, J.J., F. Dane, D. Geiger, and J.W. Kloepper. 1992. Use of bioluminescence for detection of genetically engineered microorganisms released in the environment. Appl. Environ. Microbiol. 28:267-273.

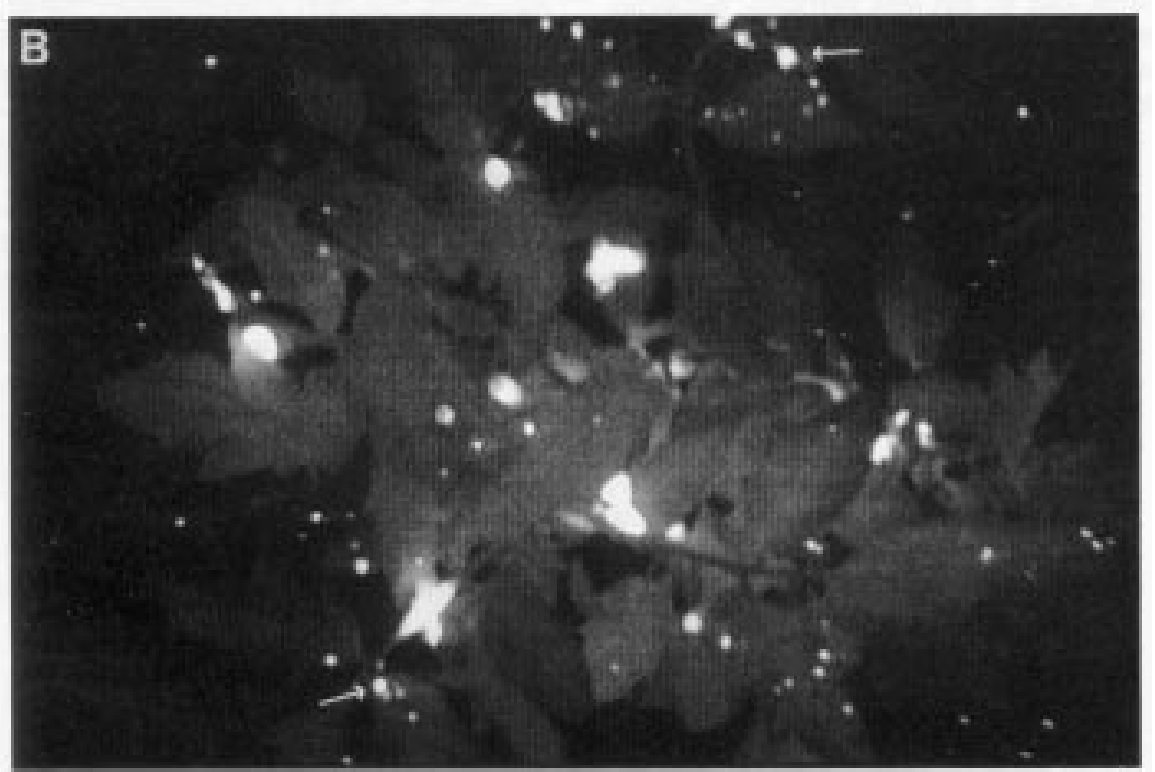

Shaw, J.J. and I. Kahn. 1993. Efficient transposon mutagenesis of Xanthomonas campestris pv. campestris by high voltage electroporation. Biotechniques 14:556-557.

Stall, R.E. and A.A. Cook. 1966. Multiplication of Xanthomonas vesicatoria and lesion development in resistant and susceptible pepper. Phytopathology 56:1152-1154.

Fig. 2. Bacterial bioluminescence in planta. Bacterial spot-susceptible 'Sunny' tomato plants illuminated by (A) incident light or (B) bacterial bioluminescence 7 days after wound inoculation with bioluminescent Xanthomonas campestris pv. vesicatoria. Arrows point to two of the locations with systemic bacterial population development. 